\title{
Ortadoğu Coğrafyasında Deaş: Tarihçesi, Eylemci Profili ve Propaganda Faaliyetleri * $^{*}$
}

\author{
Deash in The Middle East: History, Activist Profile and Propaganda \\ Activities
}

\author{
Mehmet TELTIK **
}

$\ddot{O} z$

Terör dünyada toplumsal, siyasi, ekonomik, hatta mekânsal çoklu etkileri olan bir olaydır. Son 10 yılda dünya ve ülkemiz kamuoyunu terör açısından en yakından ilgilendiren gelişme Ortadoğu'da ortaya çıkmış DEAŞ yapılanmasıdır. Çok kısa sayılabilecek bir zaman diliminde, alansal olarak geniş bir coğrafyada hâkimiyet kazanmıştır. Dönem dönem gücü zayıflasa da Ortadoğu coğrafyasındaki etkisi devam etmektedir-Bu çalışmada DEAŞ Terör Örgütü'nün ideolojik ve ekonomik yönelimleri incelenmiş tarihi gelişimi, propaganda ve eylem yöntemleri detaylıca ele alınmış ve belli çözümlemelerde bulunulmuştur. Çalışmanın temel amacı örgütün eylemci profilini ortaya çıkarmak ve buna bağlı olarak makro ölçekte örgütü temsil ettiği bilinen Rumiyah, Konstantiniyye ve Dabiq dergileri üzerinden propaganda faaliyetlerini açığa çıkarmaktır. Çalışmada nicel ve nitel yöntemler beraber kullanılmıştır. Özellikle eylemci profilinde Gaziantep Adliyesi'nden alınan veriler referans alınmış ve betimsel olarak çalışmanın amacı kapsamında kullanılmıştır. Dergilerin analizinde ise örgütün propaganda yapısını açığa çıkarmak amacıyla MAXQDA 12 programından faydalanılmıştır. Elde edilen sonuçlar göstermiştir ki DEAŞ Terör Örgütü, üyelerini ve sempatizanlarını zinde ve güçlü tutmak amacıyla propagandayı aktif bir şekilde kullanmaktadır. "Allah", "İslam”, "Müslüman", "Cihat”, "Şehit”, "Kafir", "Mürted”, "Hilafet” ve "Tağut”, gibi sözcüklerin dergilerin tamamında propaganda aracı olarak kullanıldığı tespit edilmiştir. Çalışmanın temel öngörüsü, örgütün Ortadoğu Coğrafyasındaki gücüne paralel şekilde propaganda faaliyetlerinin dönem dönem artıp, dönem dönem azalacağı üzerinedir. Ayrıca Türkiye'nin bahsi geçen dergilerin ilerleyen yıllardaki sayılarında da düşman olarak tanıtılması halinin devam edeceği düşünülmektedir. Bu durum örgüt üyelerinin temel motivasyonunu sağlamada önemli bir yöntem olarak karşımıza çıkmaktadır.

Anahtar Kelimeler: Ortadoğu, Terör örgütü, DEAŞ, Terörist, Ortadoğu coğrafyası.

\begin{abstract}
Terrorism is an event that has multiple social, political, economic and even spatial effects in the world. In the last 10 years, the development that most closely concerns the world and our country's public opinion in terms of terrorism is the DEASH organization that emerged in the Middle East. In a very short period of time, it gained dominance over a wide geographical area. Although its power weakens from time to time, its influence in the Middle East continues. Various researches are carried out from different branches of science on the actions and activities of DEASH. In this study, the ideological and economic orientations of the DEASH Terrorist Organization were examined, its historical development, propaganda and action methods were discussed in detail and certain analyses were made. The main purpose of the study is to reveal the activist profile of the organization and, accordingly, to reveal the propaganda activities through the journals Rumiyah, Konstantiniyye and Dabiq, which are known to represent the organization on a macro scale. Quantitative and qualitative methods were used together in the present study. Especially in the activist profile, the data taken from Gaziantep Courthouse was taken as a reference and used descriptively within the scope of the study. In the analysis of the journals, the MAXQDA 12 program was used to reveal the propaganda structure of the organization. The results obtained indicate that the DEASH Terrorist Organization actively uses propaganda to keep its members and sympathizers fit and strong. It has been found out that words such as "Allah", "Islam", "Muslim", "Jihad", "Martyr", "Infidel", "Apostate", "Caliphate" and "Taghut" are used as propaganda tools in all of the journals. The basic prediction of the study is that the propaganda activities will increase from time to time and decrease from time to time in parallel with the power of the organization in the Middle East Geography. In addition, it is thought that Turkey will continue to be introduced as an enemy in the following issues of the aforementioned journals. This situation emerges as an important method in providing the basic motivation of the members of the organization.
\end{abstract}

Keywords: Middle east, Terrorist organization, Deash, Terrorist, Middle east geography.

\footnotetext{
* Bu çalışma 2019 yılında Gaziantep Üniversitesi Sosyal Bilimler Enstitüsü Güvenlik Stratejileri ve Yönetimi Ana Bilim Dalı'nda hazırlanan "Irak-Şam İslam devleti IŞID/DEAŞ: İdeolojisi, Yapısı, Propaganda Araçları ve Eylemleri" adlı yüksek lisans tezinin ilgili bölümlerden faydalanılarak oluşturulmuştur.

** Uzman, teltikmehmet@,gmail.com
}

Teltik, M., (2022). Ortadoğu Coğrafyasında Deaş: Tarihçesi, Eylemci Profili ve Propanda Faaliyetleri, Asia Minor Studies, Cilt 10 Sayı 1, 92-104, Gönderim tarihi: 18-11-2021, Kabul tarihi: 29-01-2022.

Araştırma Makalesi. 


\section{Giriş}

Terör ve bunun sonucunda ortaya çıkan faaliyetler, bütün dünya ülkelerini yakından ilgilendiren bir konudur. Dünyada terörün coğrafi kaynağı farklılıklar gösterse de hâkim bakış açısı Ortadoğu'yu kriminalize etmek üzerinden şekillenmektedir. Dolayısıyla Türkiye böyle bir coğrafyada dönem dönem farklı grupların terör faaliyetleriyle baş başa kalabilmektedir. Güvenlik ihtiyacı kişilerin ve devletlerin varlıklarını devam ettirebilmeleri için hayati öneme sahip olduğundan günümüzde tüm dünyada ve özellikle coğrafi konumu nedeniyle Türkiye'de en öncelikli konu olmuştur. Buradan hareketle terörden doğabilecek tehditlere karşı birey ve devletlerin güvenliğinin sağlanması ise büyük ölçüde güvenlik kuvvetlerinin gücü, kapasitesi, teknoloji kullanımı ve geliştirdiği strateji ve politikalarla alakalıdır. Türkiye'nin kültürel fay hatlarının üzerinde bulunması (Huntington, 2018) Yunanistan, İsrail ve Ermenistan gibi kutsal devlet arayışında olan ülkelerin bazı hayali topraklarını içermesi (Smith, 2018) ve emperyalist devletlerin göz diktiği önemli doğalgaz ve petrol yataklarına yakınlığı Türkiye'deki terör faaliyetleri ve tehditlerin tırmanışa geçmesinde ve süreklilik kazanmasında etkili olmuştur. Dünya genelinde olduğu gibi Türkiye'de de Terör Örgütleri ideolojik temelli, belli örgütsel yapılar barındıran ve şiddet içerikli eylemler aracılığı ile toplumda korku, bıkkınlık, yılgınlık duygusunu oluşturup, halk üzerinde devletin siyasi otoritesine olan güven duygusunu zedeleyip bir kaos ortamı oluşturmayı hedeflemektedir (Helvacıköylü, 2007; Şen, 2015). Bunlar Ulusal olabildikleri gibi Uluslar ötesi karakterde de olabilirler. Bunlardan bir tanesi de son yıllarda ön plana çıkmış olan ve tüm dünyayı etkilemiş DEAŞ’tır.

DEAŞ, 1999 yılında Ebu Musab el-Zerkavi tarafından Afganistan'da Tevhit ve Cihat Örgütü adı altında kurulmuş, 2004 yılında ise El-Kaide ile bağlantılı hale gelerek Irak ElKaidesi adını almıştır (Erdoğan \& Deligöz, 2015). 2006 yılı sonlarında ise örgütün lideri örgütün adını "Irak İslam Devleti" olarak değiștirmiş, daha sonra Arap Bahar'ında yaşanan gelişmelerin de etkisiyle 2013 yılında ismini "Irak Şam İslam Devleti" olarak tekrardan değiştirmiştir. 2014 yılı ortalarında İslam Devleti olarak anılmaya başlanmıştır (Ayhan \& Çiftçi, 2018, s. 17-32). DEAŞ başlangiçta sadece kurulmuş olduğu coğrafi mekân içerisinde faaliyet göstermiştir. Süreç içerisinde yaptığı eylemler ve sosyal paylaşım ağları ile tüm dünyaya kendisini tanıtmıştır (Şenol vd., 2016, s. 277-292). DEAŞ ve onun gibi örgütler sadece sosyal veya siyasi boşluklardan dolayı ortaya çıkmamış devlet yapısının zayıflaması, bölgesel jeopolitik, diş askeri müdahaleler gibi sebeplere bağlı olarak var olma ve devamlılık süreçlerini şekillendirmişlerdir (Yeşiltaş \& Duran, 2018). Radikal İslami bir örgüt olan DEAŞ günümüzde dünyanın her tarafında eylem yapma kabiliyeti nedeniyle en etkili terör örgütlerinden biri olarak değerlendirilmektedir.

Son yıllarda görsel ve yazılı medyada sıkça tartışılmasına rağmen, farklı bilim dallarının katkı yaptığı akademik çalışmalarda da örgüt çeşitli yönleriyle incelenmiştir (Ekşi, 2017, s. 4372; Manaz, 2020, s. 58-79; Yaşa \& Y1lmaz, 2020, s. 107-130; Öztop, 2021, s. 97-131). Günümüzde Türkiye açısından büyük bir sorun olan DEAŞ'ın tüm yönleriyle incelenmesi bir zorunluluktur. Fakat yapılan çalışmalarda örgüt üyelerinin motivasyonunu araştırmak, temel motivasyonlarını belirlemek çoğu zaman ihmal edilmektedir. Bu çalışma böyle bir sorunsallık üzerinden hareket ederek DEAŞ Terör Örgütü'nün ideolojik ve ekonomik yönelimlerini incelemiş tarihi gelişimi, propaganda ve eylem yöntemlerini detaylıca ele almış ve belli çözümlemelerde bulunulmuştur. Çalışmanın temel amacı örgütün eylemci profilini ortaya çıkarmak ve buna bağlı olarak makro ölçekte örgütü temsil ettiği bilinen Rumiyah, Konstantiniyye ve Dabiq dergileri üzerinden propaganda faaliyetlerini açığa çıkarmaktır. Elde edilen sonuçlar göstermiştir ki DEAŞ Terör Örgütü, üyelerini ve sempatizanlarını zinde ve güçlü tutmak amacıyla propagandayı aktif bir şekilde kullanmaktadır. "Allah", "İslam", "Müslüman" gibi sözcüklerin dergilerin tamamında propaganda aracı olarak kullanıldığı tespit 
edilmiştir. Çalışma bu sonuçları itibariyle literatüre önemli bir katkı yapmayı amaçlamaktadır. Bu katkı hali aynı zamanda çalışmanın önemini de ortaya koymaktadır.

Çalışma DEAŞ'a dair genel bir tanım ve çalışmanın amaç ve öneminin belirtildiği giriş bölümüyle başlamaktadır. $\mathrm{Bu}$ kısmı, çalışmada kullanılan temel malzemenin tanıtıldığı metodoloji kısmı takip etmektedir. Üçüncü kısım ise Bulgular ve Analizlerdir. Burada taranan dergilerdeki temel analizler yorumlanmakla birlikte DEAŞ'ın eylemci profili okuyucuya tanıtılmaktadır. Çalışma sonuç bölümüyle son bulmaktadır.

\section{DEAŞ Terör Örgütü’nün Kuruluşu ve Olușum Süreci}

DEAŞ Terör Örgütü ve benzeri devlet dışı silahlı aktörler sadece sosyal veya siyasi boşluklardan dolayı ortaya çıkmamış, devlet yapısının zayıflaması, topraksal talepler, bölgesel jeopolitik, dış askeri müdahaleler gibi sebeplere bağlı olarak var olma ve devamlılık süreçlerini şekillendirmişler (Yeşiltaş ve Duran, 2018, s. 20-25). İslam coğrafyasındaki ülkelerin demokratik olarak yönetilememesi ve yönetim şekillerindeki adaletsiz anlayış ve batılı ülkelerin bunları bahane ederek bu ülkelere savaş açması, dünyanın İslam coğrafyasında yaşanan haksızlığa ve zulme sessiz kalması ve bu coğrafyada yaşayan bireylerde çaresizliğin artmasına neden olmuştur. Bölgede gerçekleştirilen sinsi politikalar, halkı 1rklar/mezhepler üzerinden ayrıştıran ve birbirine düşman eden uygulamalar, kesintisiz hale getirilen şiddet, hapis ve işkenceler, yurtlarından uzaklaşmaya mecbur kalan binlerce insan, radikal eğilimli örgütlere istedikleri ortam ve firsatı vermiş (İçişleri Bakanlığı, 2018, s. 11-12) ve böylelikle DEAŞ adı verilen gayr-i insani bir örgütün ortaya çıkması için zemin her yönden hazır hale gelmiştir (Din İşleri Yüksek Kurulu, 2016, s. 3).

DEAŞ Terör Örgütü, Ebu Musab el-Zerkavi'nin liderliğinde 1999 yılında “Cemaat el Tevhid vel Cihad" adı altında Afganistanda kurulmuştur. 2001 yılında Irak'ın Kuzey Bölgesi'ne gelerek burada faaliyet göstermeye başlayan örgüt, 2003 y1lında ABD'nin Irak'1 işgal etmesinin hitamında ABD kuvvetlerine karşı yaptığ (İçişleri Bakanlığı, 2017, s. 6; Sandıklı, 2015, s. 16; Şenol vd., 2016, s. 279; Din İşleri Yüksek Kurulu, 2015, s. 7). Ebu Musab el-Zerkavi liderliğinde kurulan "Cemaat el Tevhid vel Cihad" örgütü 2004 yılında El Kaide Terör Örgütü'ne "biad” etmiş ve "Irak el Kaide” si ismini kullanmıştır. Örgüt 2006 yılı başlarında bazı küçük gruplarla gücünü birleştirerek "Mücahitler Şura Konseyi" adını almış ve 2006 yılı sonlarında örgütün lideri örgütün adını "Irak İslam Devleti” şeklinde değiştirmiş. Örgütün lideri olan Ebu Musab el-Zerkavi'nin 2006 yılında öldürülmesininin ardından Ebubekir el-Bağdadi örgütün yeni lideri konumuna gelmiştir. Özellikle Baas Partisi'nin içerisinde geçmiş dönemde faaliyet göstermiş insanların örgüte destek vermesiyle büyüyen Örgüt Arap Baharı'nda yaşanan gelişmelerin de etkisiyle 2013 yılında ismini DEAŞ (Irak Şam İslam Devleti) olarak değiştirmiş ve 2014 yılı ortalarında adını "İslam Devleti” olarak ilan etmiştir (İçişleri Bakanlığı, 2017: 6; Ayhan ve Çifçi, 2018, s. 1922).

DEAŞ Terör Örgütü Irak Devleti içerisinde ele geçirerek kontrolünü sağladığı topraklar sonrası, sınırları belli olmasa da gücü, savaşçılarının erişiminin bulunduğu her coğrafyaya uzanan, askeri veya idari lidere (emir) kesin biat üzerine kurulu, modern bir devletin sunduğu tüm hizmetleri sağlayabilecek olmasa da çatısı altında yaşayanların manevi ve dünyevi durumlarını iyileştirmek adına mutlak adalet vaadinde bulunan Irak İslam Devleti modeli, DEAŞ Terör Örgütü'nün özellikle 2014-2017 yılları arasında Suriye ve Irakta kurduğu egemenliğin ana çerçevesini oluşturmuştur (Eroğlu, 2018, s. 205). Dünya'nın farklı kıtalarda bulunan Boko Haram gibi Terör Örgütleri'nin DEAŞ Terör Örgütü’ne biad etmesi, DEAŞ Terör Örgütü'nün yayılma çabalarının somutlaştırılması açısından önemli bir örnektir (Konstantiniyye 1, 1436, s. 34-36). 


\section{DEAŞ Terör Örgütü’nün Amacı, İdeolojisi, Stratejisi ve Radikalleşmesi}

Bazı Terör Örgütleri yapmak istedikleri eylem ve fiilleri örgüt üyelerine kabul ettirmek için onların inançlarını kullanmaktadır. Örgüt eylem ve faaliyetlerini yerine getirebilmek adına sorgulama yapmayan ve verilen talimatları yorumsuz uygulayan elemanlarla çalışmayı arzu ederler. Örgüt mensuplarının faaliyetlerini, görevlerini başarılı bir şekilde yapması için belirli bir moral ve motivasyona sahip olmaları gerekir ve bununda en kolay yönü inançları üzerinden etkilenmektir (Cinoğlu ve Özeren, 2009, s. 21). Günümüzde dini öğretileri kendi lehine kullanarak şiddeti meşrulaştırıcı bir güç haline getiren en önemli Terör Örgütü DEAŞ Terör Örgütü'dür.

Gerçekten de DEAŞ Terör Örgütü'nün, sosyolojik ve psikolojik etkileri özenle planlanmış eylem şekilleri ile propaganda yöntemleri arasında bir bütünlük ve uyum bulunmaktadır. DEAŞ Terör Örgütü, bu bütünlük ve uyum üzerinden önemli etkiler oluşturmayı hedeflemektedir. DEAŞ Terör Örgütü'nün bireysel ve kitlesel psikolojiyi kendi lehine yönlendirmeye çalıştığı ilk etki, insan zihninde dehşet hissi uyandıran acımasız eylemlere ait video kayıtları aracılığıyla potansiyel kurbanların, hakimiyet altında bulundurdukları bölgelerde yaşayan halk ve düşmanlardan oluşan üç hedef grubunun kalplerine korku salması şeklinde oluşturulmaktadır. İkinci önemli etki ise, bahse konu eylemlere ait kışkırtıcı yayınlar üzerinden dini radikalleşmeye elverişli şahısların örgüte katılımını teşvik etmek ve yönlendirmektir. Büyük bir kıta sahanlığını kontrol etme odaklı yapılan çalışmalar, DEAŞ Terör Örgütü'nün ana eylemsel stratejisini oluşturmaktadır. Bu strateji, çok çeşitli şiddet ve saldırı pratiklerini bünyesinde barındıran düzensiz bir askeri savaş öğretisine sahiptir. $\mathrm{Bu}$ stratejik anlayış, örgütün gerçekleştirdiği bütün terör eylemlerinin içeriğinde de kendini göstermiştir. Bu strateji çerçevesinde DEAŞ Terör Örgütü için varlık, faaliyet ve mücadele alanı üç ana coğrafyadan meydana gelmektedir. İlki kurulduğu ve geliştiği ülkelerde oluşan "İç Alan", ikincisi genişleme alanındaki Kuzey Afrika ile Orta Doğu'yu kapsayan "Yakın Çevre", üçüncüsü ise Asya, Avrupa ile Amerika Birleşik Devletlerini kapsayan "Uzak Dış Çevre"dir. Askeri eylem stratejisi melez bir yapıya sahip olan örgütün her bir coğrafyaya yönelik stratejileri ve mücadele teknikleri farklılık göstermektedir (İçişleri Bakanlığ 1,2017 , s. 6).

Örgütün inançları anlama şeklinde selefilik akımı geniş yer tutmakta ve bu doğrultuda özellikle eklektizm ve pragmatizm (faydacılık) ön plana çıkmaktadır. İnançlarla ilgili kutsal kitaplarda yazılı olan ve istenilenlerin ne olduğu önemli değildir, önemli olan yazılı kuralların örgütün isteklerine çevrilebilirliğidir (Okur, 2017, s. 27). DEAŞ Terör Örgütü üyeleri ilmi yeterliliğe sahip olmadıkları halde ayet, hadis ve benzerlerinden çıkarımlar yapmaya çalışmakta, ayet ve hadislerden çıkarımlar yapmaya çalışırken, öncesini ve sonrasını dikkate almaksızın bağlamından koparmakta, konuyla ilgili diğer delilleri karartmakta ve dinin temel amaçlarını önemsemeksizin yorumlamaktadır. DEAŞ Terör Örgütü üyeleri yalnızca metinden ve lafzî anlamdan hareketle ayetleri yorumlayarak hüküm verme teşebbüsleri de göstermektedir (İçişleri Bakanlığı, 2018, s. 5-19). DEAŞ Terör Örgütü'nün, ayet ve hadisleri anlamından saptırmak suretiyle kuralları ve karartarak insanların inançla ilgili duygu ve düşüncelerini önemsemeksizin yorumlarda bulunmasının meşru bir temeli olmadığı ve olamayacağı ortadadır. DEAŞ Terör Örgütü ve benzeri örgütler, bünyesinde dini bilgileri olan insanlar barındırmayan ve modern bir niteliğe bürünmeye çalışan oluşumlardır. DEAŞ Terör Örgütü gibi yapılara destek vermeyen din bilginleri düşüncelerine değer verilmeyerek yok sayılır ve bunlar her türlü kötü harekete maruz bırakılabilir. Sonuç olarak güvenilir kaynaklarla doğrulanmayan ve desteklenmeyen, fikirler, düşünceler ve eylem hareketleri için uygun bir zemin meydana getirilmektedir (Din İşleri Yüksek Kurulu, 2016, s. 6-8). Bu bağlamda hedeflerine ulaşmak isteyen DEAŞ Terör Örgütü'nün ideolojisi, üyeleri haricindeki insanları 
“müşrik" olarak nitelendirmiş ve kendisinden olmayanları düşman kabul etmiştir (Biçer, 2015: 11).

Kendi hakimiyet sınırları içerisinde yaşayan insanları "Müslüman" olarak kabul eden DEAŞ Terör Örgütü'nün kendisinden olmayan Müslümanlar'a karşı tavrı ayırt edici, ötekileştirici ve tekfir edici şekildedir. Yani örgüte itaat etmeyen, örgütün radikal söylemlerini kabullenmeyen, ibadet hayatında eksikler olan kişi DEAŞ’a göre Müslüman değildir çünkü örgüt ideolojisine göre; "Iman; kalp ile tasdik, dil ile ikrar ve amellerin ifasından ibarettir. Bu üçünden birinin eksik olması kişiyi dinden çıkarır”.

DEAŞ'ın bu yanlış mümin ve Müslüman anlayışı, amelinde eksiklik gördükleri kimseleri küfürle itham etmelerine ve öldürmelerine sebep olmaktadır. Dinin hikmet boyutunu bir kenara bırakarak sadece lafza ve şekle önem veren DEAŞ Terör Örgütü'nün bu zihniyeti, taassup ve düşmanlığı körüklemekle birlikte ve gerçekçi, derinlikli, yapıcı değil aksine ön yargılı, yüzeysel ve yıkıcıdır. Mesela, "Biliniz ki yaratma da emir de yalnız O'na aittir (Araf, 7).” ayeti, DEAŞ Terör Örgütü'nden elde edilen bilgilerde Türkiye Cumhuriyeti'nde yapılan siyasi ve yerel seçimlere katılım gösterilmemesi istenmiştir. Bir başka örnekte, örgütün, Kur'an'1 yüzeysel ve seçmeci bir tarzla okumayı önerdiği, hiçbir ön bilgi ve donanım olmaksızın Kur'an'a yaklaşmayı telkin ettiği görülmektedir. Bu telkin, örgütün stratejisindeki ilkesizliği gösteren çarpıcı bir örnektir. Cihad ayetlerinin hangi şartlarda ve hangi ayet grupları içinde indiği bilinmeden, Kur'an'ın cihad hakkındaki ilkeleri bir bütün olarak değerlendirilmeden, Hz. Peygamber' in cihada dair söz ve uygulamaları öğrenilmeden sadece tekil ayetleri okumak büyük yanılgıdır (İçişleri Bakanlığı, 2018, s. 22-25).

DEAŞ Terör Örgütü’nün insan kaynağını çoğunlukla gençler oluşturmaktadır. Bu genç kitleyi dört grupta ele almak mümkündür (İçişleri Bakanlığı, 2018, s. 15-16): Bunlardan birincisi, yıllardır savaş bölgelerinde şiddetin ve vahşetin gölgesinde büyümüş, ekonomik ve sosyo-kültürel açıdan düşük profilli kişilerdir. Bu bireylerin büyük bir kısmının okuma yazma bilmediği, herhangi bir din eğitimi almadığı bilinmektedir. Örgüte katılan ikinci kitle, "sömürge muhaciri" olarak adlandırılan iki ya da üçüncü nesil göçmen gençlerden oluşmaktadır. Bu gençler Avrupa'da doğmuş ve büyümüş fakat Avrupa toplumuna adapte olamamış, ötekileştirilmiş, aşağglanmış ve özgüvenleri zedelenmiş kişilerdir. Kendilerini ifade etme ve değer görme ihtiyaçları karşılanmayan bu gençlerin, din eğitim konusunda da yetersiz oldukları, hatta bir inanç bunalımı yaşadıkları için radikal dini söylemlere çabuk aldandıkları bilinmektedir. Gerçekten de batılı ülkelerden DEAŞ Terör Örgütü'ne katılanların büyük bir kısmının İslamiyet ile ilgisi yok denecek kadar az bilgiye sahip oldukları görülmüştür. Nitekim bu bireylerin çoğunun İslam'ı öğrenme adına taraflı bir yorum ve dille yazılan, gerçek olmayan bilgileri içeren kitapları okumaları da İslam dini hakkındaki bilgi düzeylerini göstermektedir. Çünkü bu gençlerin genellikle seküler bir çevrede yetişmiş ve bir kısmı İslam dinini yeni tanımıştır. Batılı ülkelerde yaşayıp inançları zayıf olan ve İslamiyeti Terör Örgütü aracılığıyla öğrenen örgüt mensupları, doğru bilgilendirilmeyerek yalan ve yanlış yönlendirmeler ve taraflı anlatılarla örgüt adına eylem ve faaliyetlerde bulunmuşlardır (Çakır vd., 2017, s. 5-13).

DEAŞ Terör Örgütü'nün yapmış olduğu eylemlerin batılı ülkelerde yaşayan bazı kesimlerde kabul görmesi bu taraflı anlatıların anlatıldığı kişiler açısından kişisel ve sosyal faktörlerin örtüşmesinden kaynaklanmakta ve yaşadıkları ülkelerde göçmen olarak yaşamaktan kaynaklı sorunlarla karşı karşıya kalabilmektedirler. Bu koşullar altındaki genç kitle, DEAŞ Terör Örgütü gibi grupların gündeme getirdiği gerçek olmayan dini kimlikler ile motive olmakta ve bu kimlikler onların kendini önemli hissetme, aidiyet hissi gibi ihtiyaçlarını gidermekle kalmayıp, deneyimledikleri başarısızlık, marjinalleşme, yeni heyecanlar yaşayarak farklılaştırmalarına katkı sağlamaktadır. Benzer sorunlarla karşılaşan Müslüman kitleye Terör Örgütü, insanların inançlarından dolayı, Siyonist-Haçlı ittifakının saldırısı olarakta 
nitelendirilen küresel bir saldırıya maruz kaldıklarını, kendi inancından olan insanlara DEAS Terör Örgütü'nün kalkan olduğunu, kendilerinden olmayan ancak İslam'1 kabul etmiş toplulukların konuyu anlayacak durumda olmadığını, örgüte girenin inanan Müslümanlar'a dahil olacağını, neticede istediklerini yapacağını, bu uğurda her şeyi feda edebileceklerini söyleyerek, kendince farklı bir dünyanın kapısını açmaktadır. DEAŞ Terör Örgütü bu yolla kendi tarafına çekmiş olduğu insanlarda inanç temelli bir aidiyet duygusu oluşturmaktadır. DEAŞ Terör Örgütü'ne katılan üçüncü kitle, henüz yeni Müslüman olmuş ve İslam'ı orijinal (Kur'an) bir kaynaktan, iyi niyetli, bu konuda donanımlı ve yeterli kişilerden öğrenme imkanı bulamamış gençlerden oluşan kitledir. Dini bilgi yönünden yetersizlikleri bulunan bu gençlerin Terör Örgütleri'nin ideolojik tuzaklarına çok çabuk düştüğü bilinmektedir. DEAŞ Terör Örgütü'ne katılan dördüncü kitle ise, örgütün hiyerarşik yapılarına dahil olmayan, İslam'ın cihad, şehadet, cennet gibi kutsal amaçlarının, bu örgütün söylem ve eylemleri üzerinden gerçekleştireceğine inandırılan genç kitledir. Örgüt, genç kitlenin dinî duygularını istismar etmekte, İslami kavram ve konular üzerinden oluşturduğu metinlerle onları kontrol altında tutup motive ederek yönlendirmeye çalışmaktadır. Bu şekilde bir motivasyonla örgüte katılanlar, sonradan örgütün gerçek amacını anlayıp dönmek isteseler bile, içerisine düştükleri vahşet yapılanması buna engel olmaktadır. DEAŞ Terör Örgütü'nün ideolojik alt yapısını diğer dini motifli örgütlerde de görülebilen (El Kaide, Taliban gibi) selefilik akımı oluşturmakta ve bu durum radikal İslam tezini ve Avrupa ülkelerine düşmanlığı terörizm odaklı güçlendirmiştir. Örgüte göre doğru karar Müslüman bir devletin egemen olduğu ortamda alınmakta ve tatbik edilmektedir. Selefi hareketi İslamdaki değişimleri kabul etmemekte, bu gelişmeleri inanışlarına ters geldiği şeklinde değerlendirmekte, farklı fikirlerde olanları dinsiz olarak görmekte ve yaşamaması gerektiğine inanmaktadır. DEAŞ Terör Örgütü selefi ideolojisini Marksist düşünce ve fikirlerle yoğurarak cihadi bir anlayışla uyarlamış ve kurgulamıştır. DEAŞ Terör Örgütü halifeliği elde ettiğini beyan ederek, Suriye'de yaşanan otorite boşluğundan faydalanıp Irak ve Suriye'de genişleyip, kendi inançlarına göre yönetim şekli belirleyerek yeni bir devlet kurma amacını taşımış, bulunmuş olduğu alanda hakimiyeti'ni hissettirmeyi hedeflemiştir. $\mathrm{Bu}$ hedefine ulaşmak amacıyla etnik kimlikler üzerinden kargaşa ortamı yaratarak toplumu etnik ayrımcılık (Şii) üzerinden sevk ve idare etmeyi denemiştir. Farklı mezhepteki insanlara zarar vererek kendi mezhebinden olanları yanına çekmek, bu iki ülke toprakları üzerinde bir egemenlik kurmak, süreç sonunda ise başta çevresinde bulanan Müslüman devletler olmak üzere Müslüman devletler'i kendi safına katmayı hedeflemiştir. DEAŞ Terör Örgütü propaganda amaçlı organlarında "örgütün stratejisi politik ve dinî otoritenin tesis edilmesinden önce silahlı güç aracılı̆̆ılla fiziki kontrolün sağlanması” olduğu ifade edilmiştir (Şenol vd., 2016, s. 284-285).

Dini motifli bir Terör Örgütü olan DEAŞ Terör Örgütü yapmış olduğu eylem biçimleri ve kurmuş olduğu yapının yanı sıra örgüt mensubu sayısı, kontrol altında bulundurmuş olduğu toprak parçaları ve örgütü yönetim biçimi ile kendisinden önce kurulan tüm Terör Örgütleri'nden farklı bir karakter sergilemiştir (Geyik Yıldırım, 2018, s. 175). Örgütün elinde bulundurduğu askeri güç kaynağı ve uyguladığı taktiksel strateji de diğer Terör Örgütleri’nden ayıran önemli bir nitelik olarak karşımıza çıkmaktadır (Sandıklı, 2015, s. 16). Politik dışlanma ve baskının Ortadoğu'da şiddetin üretilmesinde can alıcı bir şekilde rol aldığı görülmüştür. Güçlü Avrupa ülkelerindeki yanlış uygulamalar ve verilen yanlış mesajlar ile adaletsiz yaklaşım karşısında örgütün başkaldırması popülerliğini artırmıştır. Katı kurallara maruz bırakılan insanlar da kurtuluşu farklı alanlarda aramış, özellikle daha önce asker olarak görev yapmış insanların bu örgüte katılımı fazla olmuştur (Çakır vd., 2017, s. 6).

DEAŞ Terör Örgütü'nün düşünce ve felsefesinde insanları ayrıştırma ve kutuplaştırmaya yönelten bir yapının egemen olduğu görülmektedir. Bu düşünce biçimi ve inanç motifleri üzerinde temellenen DEAŞ Terör Örgütü, "Batı bizi eziyor, onun maşası olan 
tağut, yani yalancı İslamcılar da onlarla işbirliği yapıyor" şeklinde söylemlerde bulunarak Darü'l-Harb'in şartlarının oluştuğunun algılanmasını sağlamaya çalışmış, yapmış olduğu eylemlerin doğru ve haklı olduğunu beyan ederek insanların feda edilmesinin zeminini hazırlamıştır (Şenol vd., 2016, s. 284). DEAŞ Terör Örgütü gibi devlet dışı silahlı aktörler, dini ilkelerin öncelendiği tek başlı bir siyasi yönetim aracılığıyla uzun vadede dünya sistemini değiştirmeyi hedeflerken PKK veya PYD gibi Terör Örgütleri belirli bir devletin siyasi yapısını değiştirmeyi hedeflemektedirler (Yeşiltaş ve Duran, 2018, s. 19-20).

\section{Materyal ve Yöntem}

Çalışmada DEAŞ'ın eylemci profili ve propaganda yöntem ve araçlarını belirlemek için hem nicel hem de nitel araştırma yöntemlerinden faydalanılmıştır. DEAŞ Terör Örgütü'nün eylemci profilini belirlemede Gaziantep Adliyesi tarafindan tutulmuş 140 DEAŞ üyesinin kayıtlarından faydalanılmıştır. Buradan elde edilen veriler yaş, cinsiyet, medeni hal, eğitim ve gelir düzeyleri ile meslekleri kapsayacak şekilde betimsel analiz çerçevesinde kullanılmıştır. Bunun yanında DEAŞ’ın eylem sürecini anlamak açısından örgütün çeşitli dönemlerde yayımlamış olduğu Rumiyah, Konstantiniyye ve Dabiq adlı 3 dergi çalışmanın kapsamı içine alınmıştır. Rumiyah Dergisi'nden 13 sayı, Konstantiniyye Dergisi'nin 7 sayısına, Dabiq Dergisi'nden ise 9. sayısından faydalanılmıştır. Araştırmacının ilgili literatürden hareket ederek tespit ettiği 23 adet anahtar kelime (tağut, cihad, kâfir, mürted, hicret, şehid, küfür, hilafet, şirk, müşrik, şehadet, cennet, tekfir, cehennem, savaş̧̧ı, put, halife, irtidad, istişhad, medeni, fiten, icra, putperest), dergilerin analizindeki temel girdi olarak ele alınmıştır.

Çalışmada ilgili derginin analizini gerçekleştirmek amacıyla nitel araştırma yöntemlerinde sıklıkla kullanılan Maxqda 12 adlı programdan faydalanılmıştır. Belirlenen 23 adet anahtar kelime, programa kodlandıktan sonra her 3 derginin her bir sayısı için ayrı ayrı sözcüksel aramayla sözcüklerin dergilerdeki geçiş sıklıkları ortaya çıkarılmıştır. Buna ek olarak analizi daha derin ve anlamlı hale getirebilmek amaciyla dergiler üzerinde kodlamalar gerçekleştirilmiştir. Bu analizler Kod Matris Tarayıcısı, Kod İlişkileri Tarayıcısı ve Kelime Bulutudur. Kod Matris Tarayıcısı bir dergide ilgili kodun kaç defa kodlandığını göstermektedir. Kod İlişkileri Tarayıcısı ise hangi kodun aynı cümle içerisinde diğer bir kodla kaç defa çakıştığını analiz etmektedir. Kelime Bulutu ise bir dergideki tüm sözcükler içinde en fazla tercih edilen sözcüklerin görselleştirilmesine yaramaktadır. Ayrıca her bir kodun hangi dergide ne kadar işlendiğini gösteren betimsel analizler de ilgili bölümde gösterilmek üzere ayrı sayılar halinde analize tabi tutulmuştur. Buna ek olarak elde edilen tüm çıktıları görsel açıdan daha anlamlı hale getirmek amacıyla CorelDraw X5 programından faydalanılmıştır.

\section{Bulgular ve Analiz}

DEAŞ'ın eleman profilini kesin olarak ortaya koymak güç olsa da örgüt elemanlarının profili örneklem grubu referans alınarak belirli çıkarımlar yapılabilir. Gaziantep'te yakalanan ve hakkında işlem yapılan 140 örgüt üyesinin sınırlı bilgileri bu aşamada kullanılmıştır. İlgili veri seti 14'ü kadın 126'sı erkek örgüt üyesinden oluşmaktadır. Örgüt elemanlarının 21'i 18-25 yaş aralığında iken, 99'u 26-40 yaş grubunda ve geriye kalan 20'si ise 40 yaşın üstündedir. 23'ü bekar 117'si ise evlidir. DEAŞ Terör Örgütü'ne evlilerin daha çok katıldığı görülmektedir. 140 kişinin beyanatlarına göre analiz edilen örgüt elemanlarının 50'si 1000 TL'den daha az kazanırken 78'i 1001-2500 TL arasında aylık gelire sahiptir. Bu veriler dikkate alındığında yaklaşık \%93'ü Türkiye'de 2019 yılı asgari ücretinden daha az kazanan yoksul ve işsiz kişilerden oluşmaktadır. Eğitim düzeyleri dikkate alındığında 1 kişi okuma-yazma bilmezken, 6'sı herhangi bir diplomaya sahip olmadan sadece okur-yazardır. İlkokul mezunu olanlar ise ilk sırada olup 74 kişidir. Ortaokul mezunları ise 13 kişidir. Lise mezunu olanlar 33 kişi, lisans mezunları ise sadece 13 kişidir (Grafik 1). 


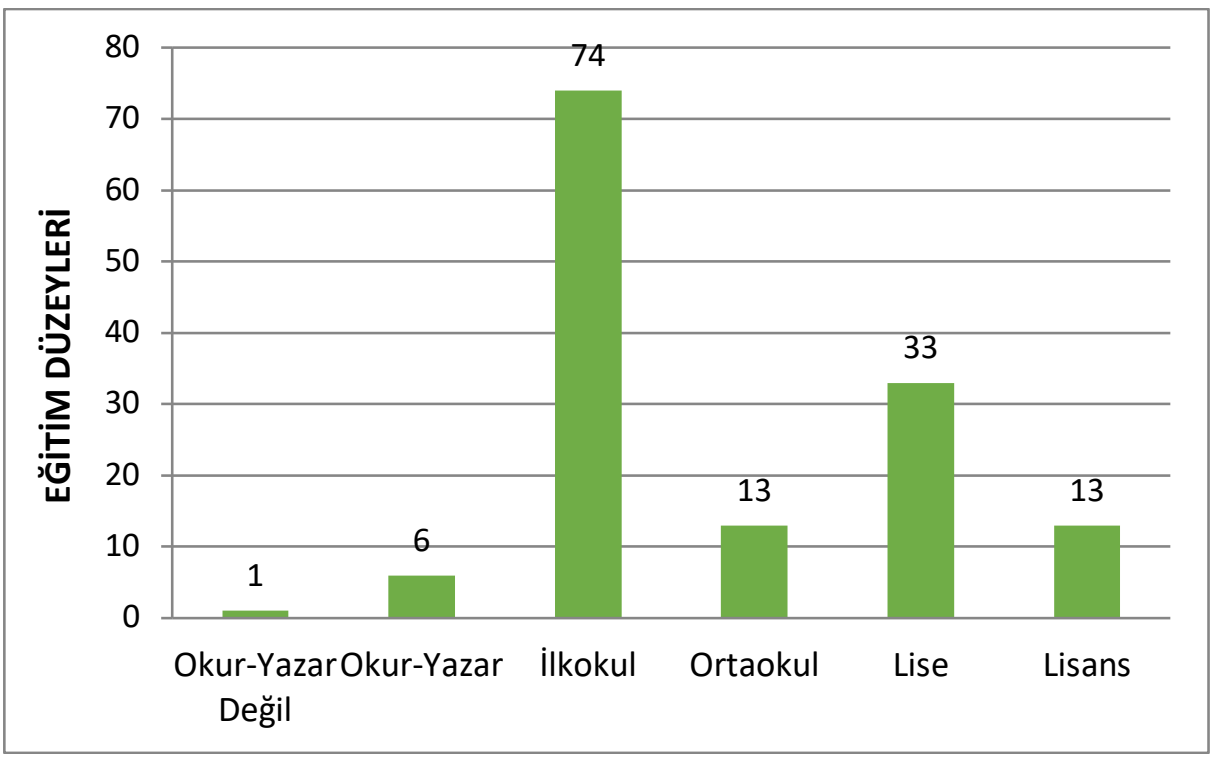

Grafik 1: DEAŞ Terör örgütü’ne mensup kişilerin eğitim düzeyleri.

140 kişinin beyanatları dikkate alınarak meslek grupları da belirlenmiştir. Buna göre bunların yaklaşık \% 36'sı uzmanlık istemeyen ve büyük ölçüde geçici olan serbest meslek grubuna dahildir. Bu grubu yaklaşık \% 23 ile işçiler ve \% 21ile esnaf olanlar takip etmektedir. 140 kişinin yaklaşık \% 8'i ev hanımı iken, işsiz, memur ve öğrencilerin oranı ise birbirine çok yakın olup toplamda \% 12 civarındadır (Grafik 2). İki kişi ise emekli olduğunu beyan etmiştir. Bu kısıtlı veriler dikkate alındığında DEAŞ Terör Örgütü'ne katılanların büyük ölçüde işçi ve belli bir uzmanlık istemeyen meslek gruplarından olduklarını ileri sürülebilir.

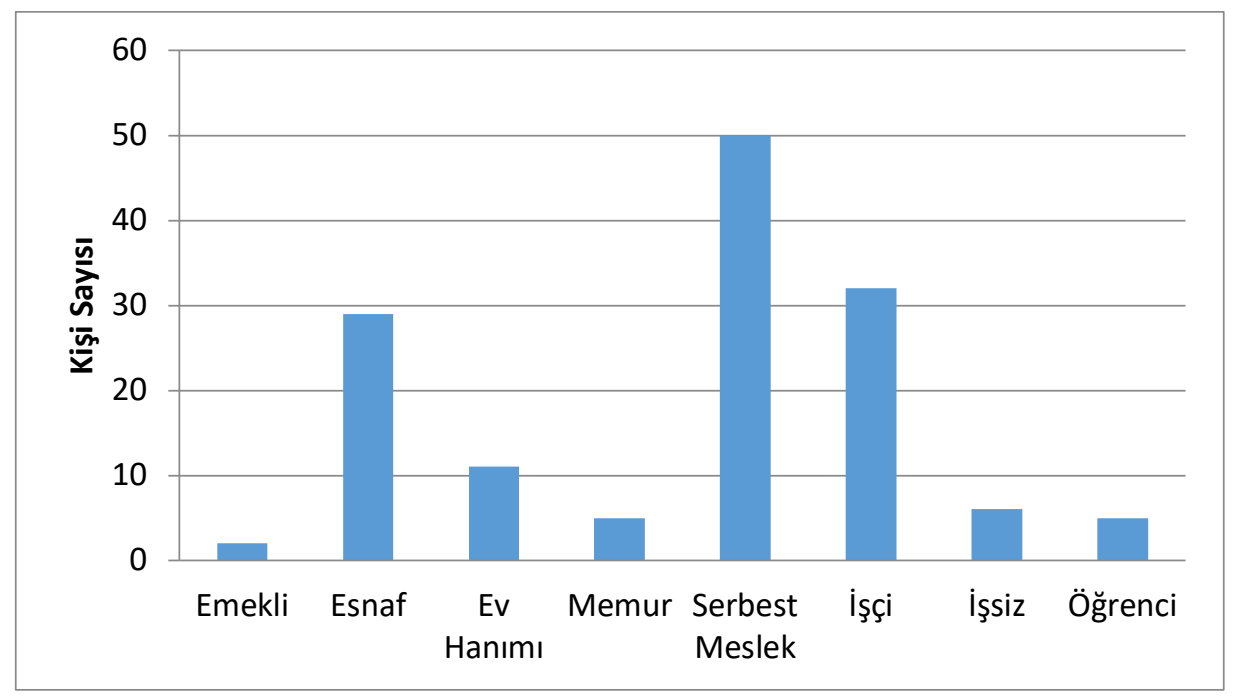

Grafik 2: DEAŞ Terör örgütü’ne mensup kişilerin meslek grupları.

Çalışmada yurtdışından DEAŞ’a katılanların sayılarına da ulaşılmıştır. 2011-2017 y1lları arasında 5510 Türk vatandaşı, 3840 kişi de yabancı uyruklu olmak üzere toplamda 9.350 kişi DEAŞ üyesi ya da irtibatlı olduğu gerekçesiyle gözaltına alınmıştır. Bunlardan 1.732'si Türk vatandaşı ve 1337'si yabancı uyruklu olmak üzere toplamda 3.069 kişi tutuklanarak cezaevine gönderilmiştir (İçişleri Bakanlığı, 2017). Türkiye’ye giriş yasağı getirilen ya da tutuklanarak sınır dışı edilenlerin sayısı da fazladır. Örgütle bağlantılı oldukları gerekçesiyle sadece Avrupa Birliği ülkelerinden Türkiye’ye girişi yasak olanların sayısı 10 bin kişi civarındadır. Avrupa Birliği ülkeleri arasında Türkiye’ye girişi yasak olanlar arasında 2.622 kişiyle Fransız vatandaşı olanlar ilk sırayı almaktadır. Bu ülkeyi 1.519 kişiyle Belçika, 1.172 kişiyle Birleşik Krallık takip etmektedir (Grafik 3). Avrupa Birliği ülkelerinden bu kadar 
katılımın yüksek olması da dikkat çekicidir. Aynı zamanda yapılan bazı çalışmalarda bu kişilerin önceden Müslüman olmayıp daha sonra Müslüman oldukları da belirtilmiştir (YILDIRIM, 2018, s. 170-182).

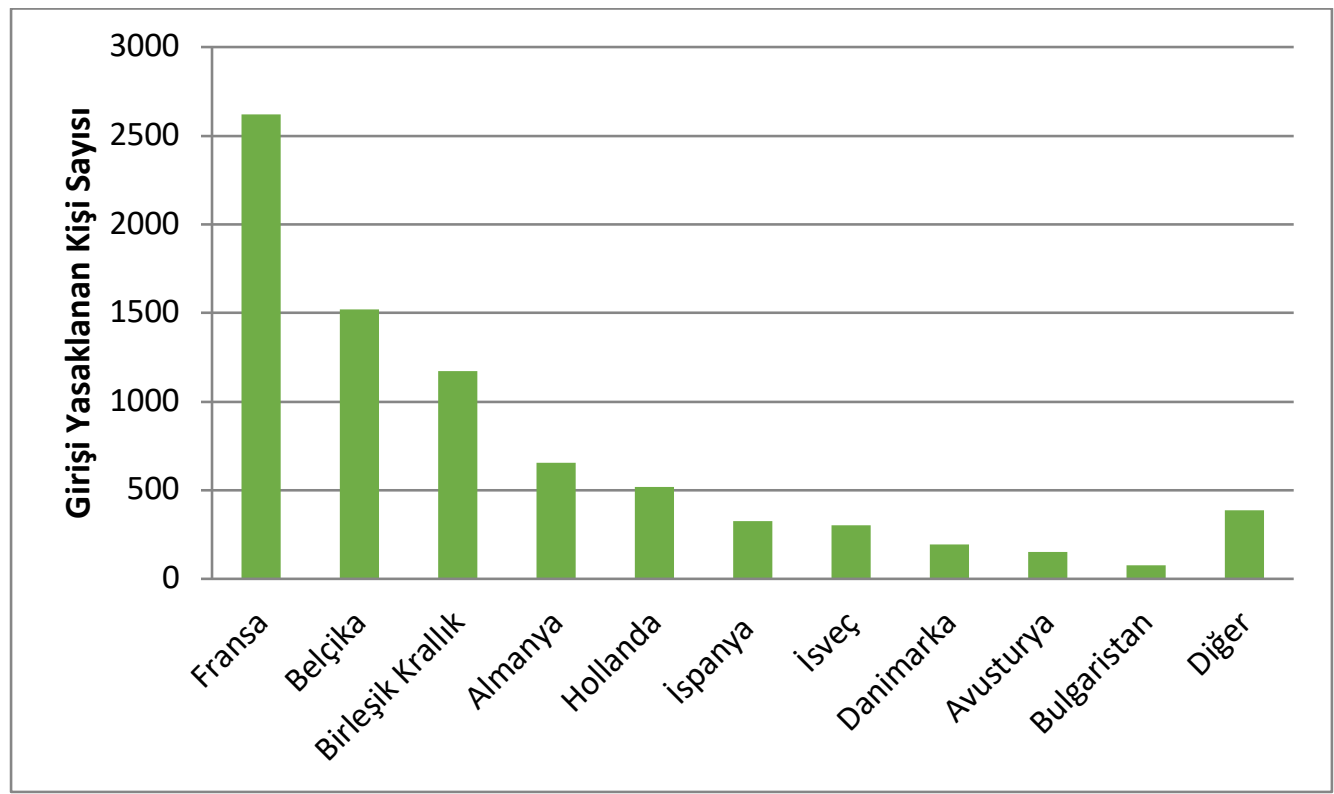

Grafik 3: DEAŞ ‘la irtibatlı olduğu gerekçesiyle $\mathrm{AB}$ ülkelerinden Türkiye’ye girişi yasaklanan kişi sayısı

DEAŞ Terör Örgütü'nün propaganda araçlarının içeriklerine dair analizler nitel araştırma programı olan MAXQDA 2012'den faydalanılarak analiz edilmiştir. Dabiq, Rumiyah ve Konstantiniyye dergilerinin analizi yapılmıştır. Kodlanan 23 anahtar kelime, dergilerin genelinde taratılmış ve kelime frekanslarının dağılımı analiz edilmiştir. Kodların aynı cümle içerisinde diğer bir kodla kaç defa çakıştığını Kod İlişkileri Tarayıcısıyla analiz edilmiştir. Ayrıca Dabiq ve Konstantiniyye dergilerinin kelime bulutu vasitasiyla yorumlanması gerçekleştirilmiştir.

Dabiq Dergisi, propaganda araçlarından biri olan 9. sayısına ulaşılmış ve analizler gerçekleştirilmiştir. Dabiq Dergisi'nin bu sayısında seçilen kelimeler arasında en fazla kullanılanı \%18,3 ile Mürted iken, \%16,1 ile Tağut ve \%15,8 ile Hilafet, \%12,7 Cihad, \%5,6 Şirk kelimesi takip etmektedir (Şekil 1). Dinden çıkmış anlamında kullanılan "Mürted" kelimesi ile haddi aşan ve şirk koşulan anlamında kullanılan "Tağut" ile ortak koşan "Şirk" kelimeleri dinen öldürülebilir kişiler olarak yorumlanabildiğinden tamamen ötekileştirici olup, DEAŞ için düşman belirlemede önemli bir motivasyon aracı olmuştur.

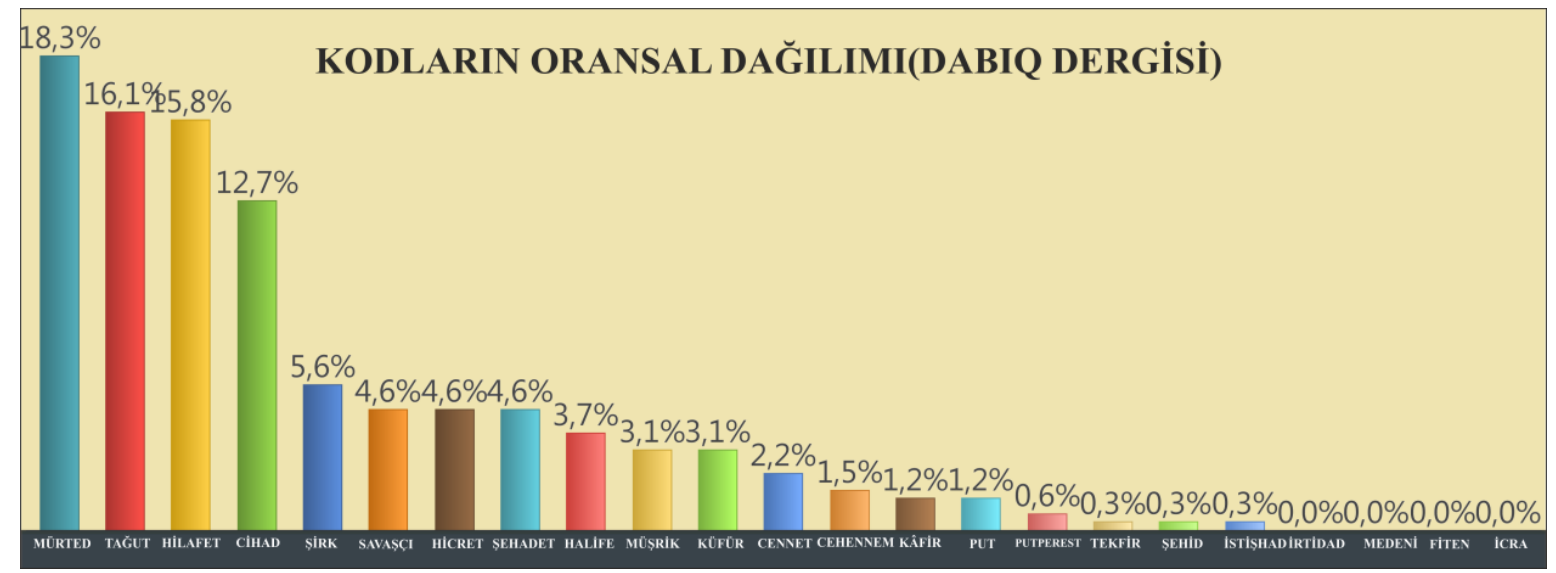

Şekil 1: Dabiq dergisinin 9. sayısında kodlanan kelimelerin kendi içindeki oransal dağılışı. 
Dabiq Dergisi’nin 9. Sayısındaki Kelime Bulut'una bakıldığında en fazla "Allah" kelimesinin vurgulandığ1 görülmektedir. "Allah" kelimesinden sonra "Onlar" kelimesi olduğu görülmektedir (Şekil 2). "Allah" kelimesi ile dini propaganda yaparken "Onlar" kelimesi ile de ötekileştirme yapılmıştır. DEAŞ'ın dergide yaptığı propaganda da düşmanı belirleyerek kimlere karşı savaş açtıklarını açıkça göstermektedir

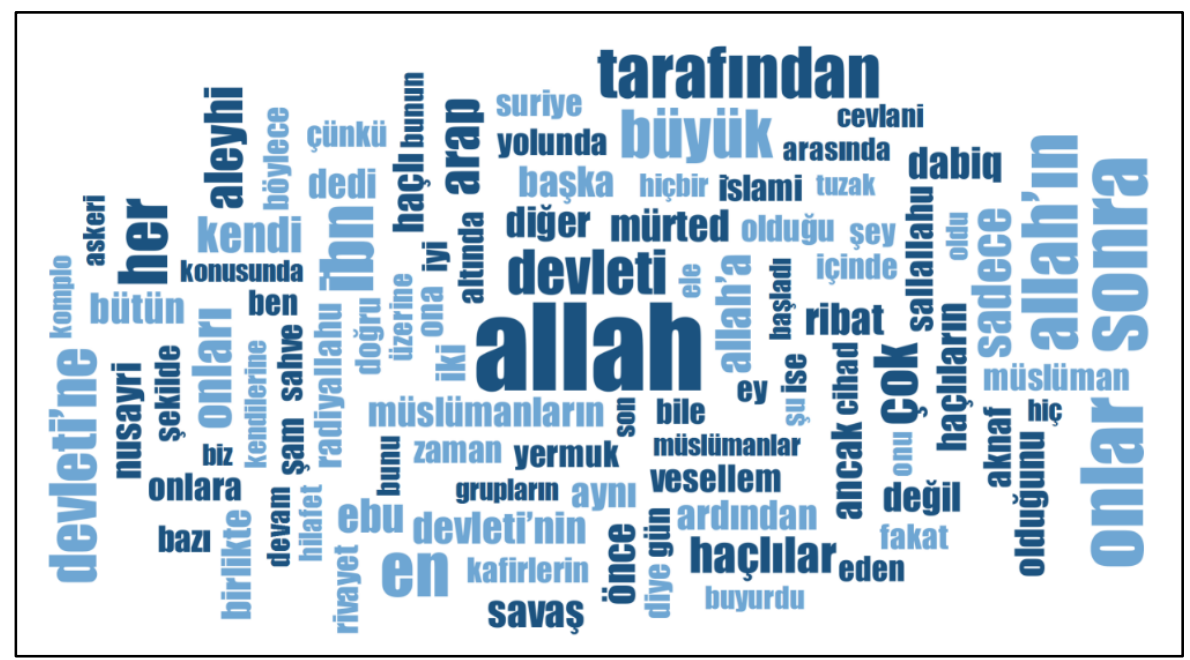

Şekil 2: Dabiq dergisinin kelime bulutu analizi

Konstantiniyye Dergisi, kodlanan kelimeler arasında \%15,2 ile Tağut ilk sırada yer almaktadır. İkinci sırayı \%11,6 ile "Cihad", \%11,5 ile "Küfür", \%8,1 "Mürted" takip etmektedir (Şekil 3). Konstantiniyye dergisinde daha çok "Cihad" ilanı yapılmaktadır. Konstantiniyye Dergisi büyük ölçüde Cihad yapılmanın gerekliliğinden dolayı Terör Örgütü savaşçılarına daha fazla hitap etmek için kullanmışlardır.

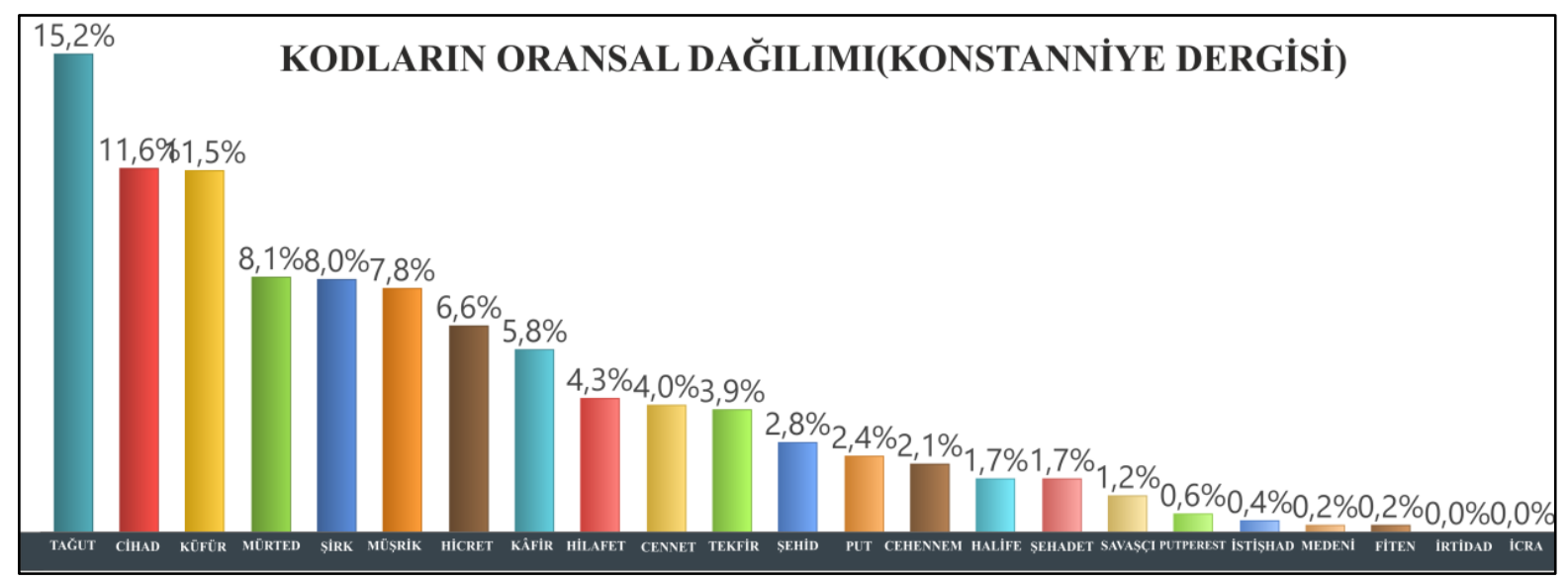

Şekil 3: Konstantiniyye dergisinde kodlanan kelimelerin kendi içindeki oransal dağıllş̧1

Konstantiniyye Dergisi'nde Kod İlişkisine baktığımızda "Şirk ve Küfür” kelimelerinin çok defa çakıştı̆̆ 1 görülmektedir. Benzer şekilde "Tağut ve Küfür", "Cihad ve Hicret” ile "Müşrik ve Tekfir” kelimelerin de yüksek oranla çakıştı̆̆ görülmektedir (Şekil 4). Bu kelimelerin anlamlarına baktığımızda Müslüman olan toplumlarda ötekileştirmeyi için kullanıldığını söylenebilir. Müslüman ülkelerin İslamiyet'i yaşamak için uygun olmadıkları, Müslüman ülkelerde yaşayan Müslümanların da küfre bulaştığı ve mürted konumuna düştüklerini kabul ettirmekte kullanılmaktadır. 


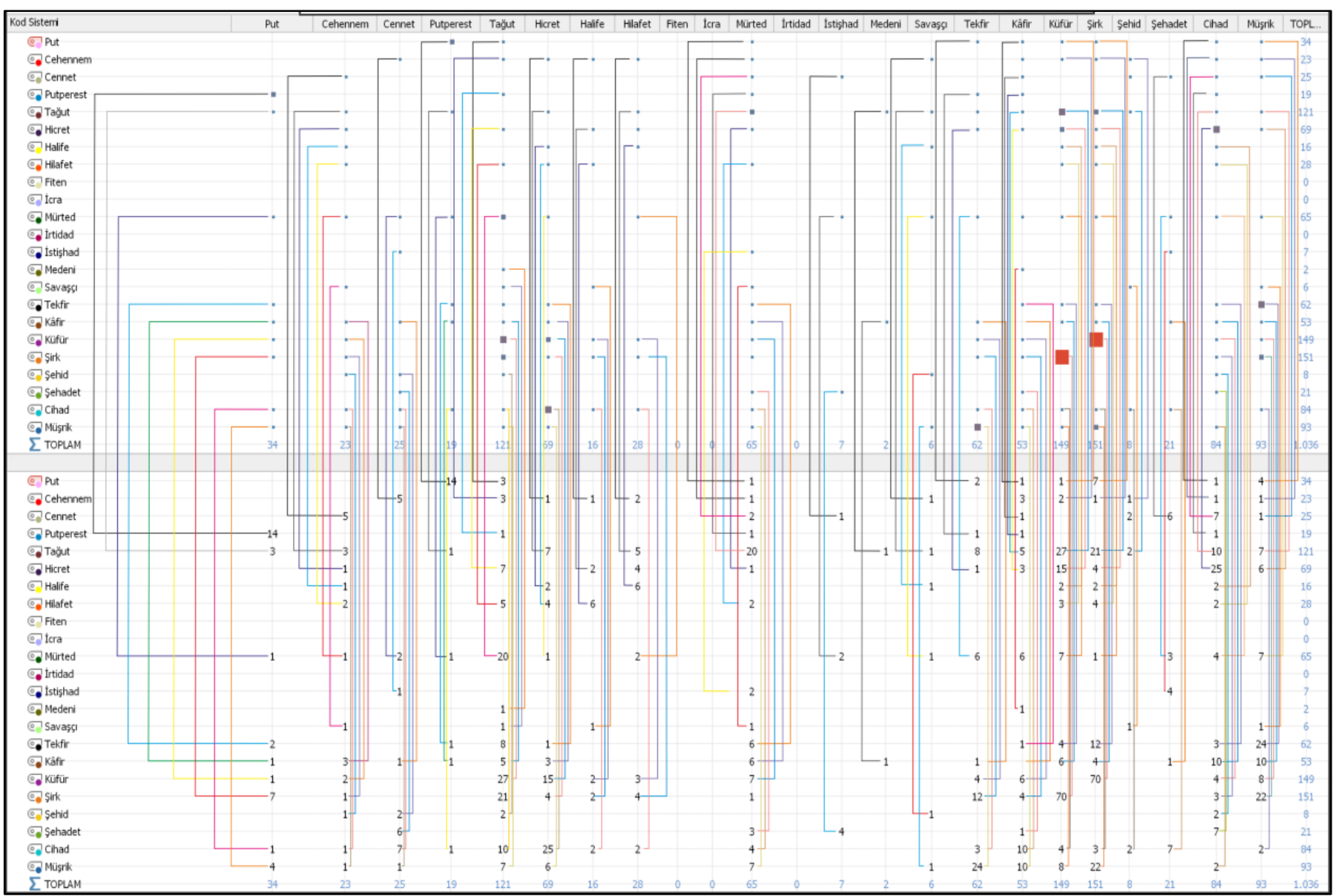

Şekil 4: Konstantiniyye dergisinde kod ilişkileri.

Rumiyah Dergisi, 13 sayısının geneline bakıldığında kodlanan kelimelerde ilk sırayı $\% 18,1$ ile "Mürted" almakta. \%10,8 ile "Hilafet", \%10,4 ile "Kâfï", \%9,3 ile "Cihad", \%8,4 ile "Tağut", \%8,3 Müşrik takip etmektedir (Şekil 5).

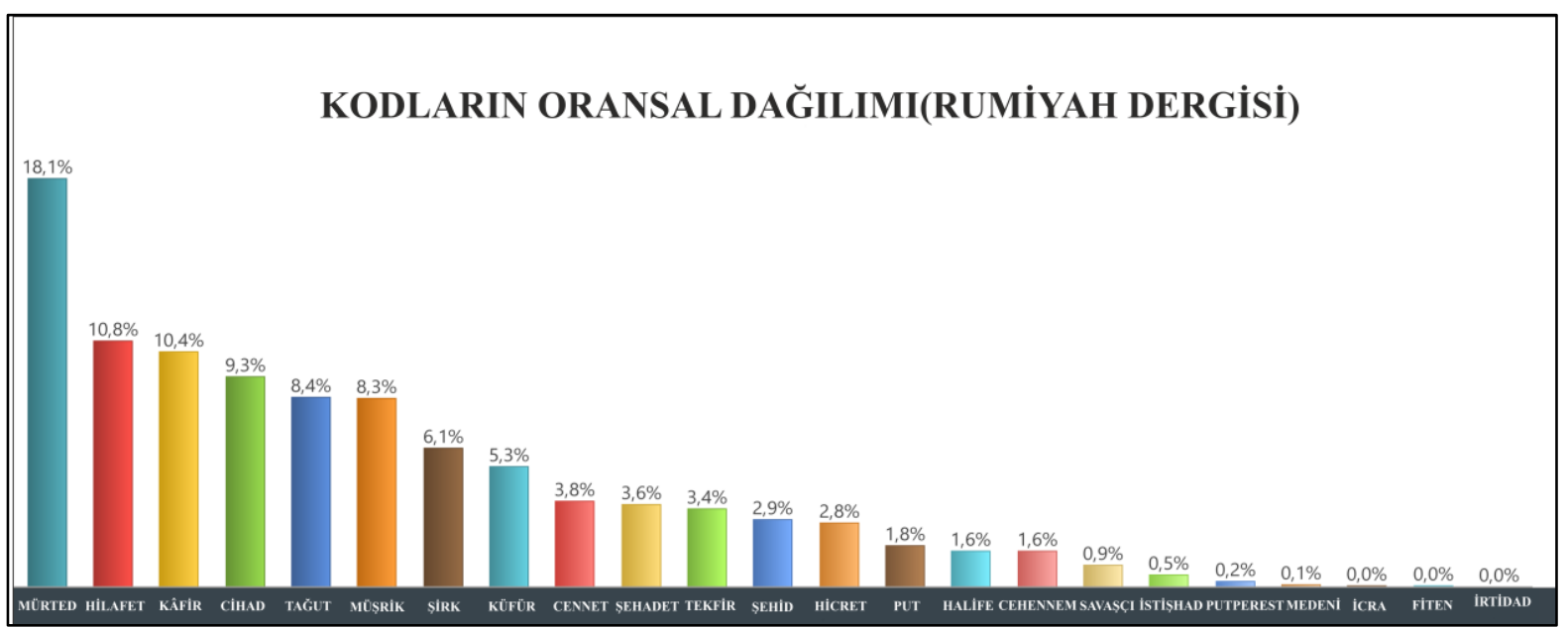

Şekil 5: Rumiyah dergisi'nde en fazla tekrarlanan kodlar.

Rumiyah Dergisi'nin 13 sayısının genelinde kod ilişkilerine bakıldığında birbirlerine zıt olan "Mürted" ve "Hilafet" kelimelerinin birbirleriyle bir arada kullanıldıkları ve birbirleriyle ilişkilendirildikleri görülmektedir. Bu kelimeler dışında "Şirk ve Küfür" birbiriyle ilişkili ve bir arada kullanılan diğer kelimelerdir. "Kafir ve Putperest", "Cennet ve Cehennem", "Kafir ve Mürted", "Kafir ve Tağut", "Mürted ve Tağut" ile "Küfür ve Tağut" gibi kelimelerin birbirleriyle ilişkisi görülmektedir. 
Dergilerin üçü de DEAŞ açısından önemli yazılı propaganda araçları olarak karşımıza çıkmaktadır. Bu dergilerin içerikleri büyük ölçüde benzer olmakla beraber ufak kısımların birbirinden ayrılmaktadır. Özellikle Müslüman toplumların gerçekte Müslüman olmayıp dinden çıkmış birer Mürted oldukları, yöneticilerin Tağut veya kabaca birer Firavun oldukları algısı, yani düşman yaratma çabası içinde oldukları görülmektedir.

\section{Sonuç}

DEAŞ Terör Örgütü'nün ideolojik yönelimleri incelenerek tarihi gelişimi, propaganda ve eylem yöntemleri detaylıca ele alınmış ve belli çözümlemelerde bulunulmuştur. DEAŞ Terör Örgütü'nün örgütün eylemci profilini ortaya çıkarılmış ve buna bağlı olarak makro ölçekte örgütü temsil ettiği bilinen Rumiyah, Konstantiniyye ve Dabiq dergileri üzerinden propaganda faaliyetlerini açığa çıkarılmıştır. Gelecekte bazı devletlerin Terörist Unsurlara-Terör Örgütleri'ne destek olma çabalarını güçleştirmesi yahut olanaksız kılması açısından terörizmi kesin çizgilerle ve net bir şekilde tanımlamak faydalı olacaktır. Türkiye'nin jeopolitik konumu düşünüldüğünde her türlü terör faaliyetine karşı hazırlıklı olması gerekmektedir. DEAŞ'ın eleman teminine yönelik yöntem ve faaliyetleri değerlendirildiğinde hedef aldığ 1 kesimi analiz ederek stratejilerini bu doğrultuda belirlediği bilinmektedir. Ağırlıklı olarak eğitim seviyesi düşük, yoksul ve muhafazakar kişilerden daha çok eleman temin ettikleri görülmektedir. $\mathrm{Bu}$ profil özelliklerine sahip elemanları terör eylemlerinde kullanmaları daha kolaydır. Türkiye'de özellikle dezavantajlı mahalle ve alanlarda sosyal, kültürel çalışmaların arttırılması gerekmektedir. DEAŞ'ın dünya genelinde körüklediği bir diğer konu ise İslam karşıtlığı veya düşmanlığıdır. Dolayısıyla tüm dünyada İslamofobi de artmasında etkili olmaktadır. İlginç bir yönü de özellikle Avrupa Birliği üyesi ülkelerden Terör Örgütü'ne katılım oldukça yüksektir. Bu ülkelerden Terör Örgütü'ne katılanların bir kısmının aileden Müslüman olmadıkları ve daha sonra Müslüman oldukları görülmektedir. Bu durumda DEAŞ’a katılan elemanların uluslar, ırklar ve dinler arası boyutta olduğunu göstermektedir. Dolayısıyla DEAŞ Terör Örgütü’ne eleman profili ile ilgili gerçek bir özetleme yapmak oldukça zordur bir konudur. DEAȘ Terör Örgütü tüm dünya ve özellikle Türkiye açısından önemli bir tehdittir. Türkiye dünyadaki tüm Müslüman ülkeler arasında demokrasinin kök saldığı, Cumhuriyet ile yönetilen ve en modern olanıdır. Bu özellikleri ile Türkiye, DEAŞ Terör Örgütü gibi dini referans gösteren radikal Terör Örgütleri tarafından büyük bir tehdit olarak algılanarak, düşman ilan edilmektedir.

\section{Kaynakça}

Ayhan, B., \& Çiftçi, M. E., (2018). IŞID, propaganda ve islamofobi, Medya ve Din Araştırmaları Dergisi, 1, 17-32.

Cinoğlu, H. ve Özeren, S., (2009). Uluslararası literatürde din ve terörizm Polis Dergisi, 15 (59-60): 21.

Çakır, F.M., Aslan, Ö., Kıyıcı, H., Söylemez, H. İ., Öztürk, M., Şahin, Y., Demirbaş, M., (2017). Radikalleşme, şiddet içeren aşırılık ve terörizm, Polis Akademisi Yayınları: 26 (8), Ankara, ss.5-42.

Din İşleri Yüksek Kurulu. (2016). Dini istismar ve tedhiş hareketi Deaş, Ankara: Diyanet İşleri Başkanlığı Din İşleri Yüksek Kurulu. Ankara, ss.2-43.

Diyanet İşleri. (2021, 11 18). Diyanet İşleri Başkanlığı . 11 18, 2021 tarihinde Diyanet İşleri Başkanlığ 1 Kuran-1 Kerim: https://kuran.diyanet.gov.tr/tefsir/A'r\%C3\%A2fsuresi/961/7-ayet-tefsiri adresinden alınd1

https://dosya.diyanet.gov.tr/DIYKDosya/YayinDosya/78e45efd-bf5d-4933-9fed-

f76da0bc5832.pdf Erişim Tarihi: 14.11.2018.

Ekşi, M., (2017). Dönüşerek varlığını sürdüren NATO’nun 2000'lerdeki yeni rolü: DEAŞ/terörizmle mücadele ve Türkiye, Bölgesel Araştırmalar Dergisi, 1(3), 43-72.

Erdoğan, Ş., \& Deligöz, E., (2015). Irak Şam İslam Devleti (IŞID): Gücü ve geleceği. Savunma Bilimleri Dergisi, 14(1), 5-37. 
Eroğlu, D., (2018). IŞİD a ğları. İletişim Yayınları, İstanbul, ss.9-478.

Geyik Yıldırım, S., (2018). Işid'in toplumsal ve küresel dinamikleri, Uşak Üniversitesi Sosyal Bilimler Dergisi, 11(6): 170-182. http://dergipark.gov.tr/download/ article-file/521794 Erişim Tarihi:18.10.2018.

Helvacıköylü, G., (2007). "Terör nedir?". Türk Asya Stratejik Araştırmalar Merkezi, http://www.tasam.org/tr-TR/Icerik/515/teror_nedir Erişim Tarihi:17.02.2019.

http://www.aljazeera.com.tr/haber/isid-hilafet-ilan-etti Erişim Tarihi: 25.04.2019.

Huntington, S. (2018). Medeniyetler Çatışması ve Dünya Düzeninin Yeniden Kurulması. İstanbul: Okuyan Us Yayınları.

İçişleri Bakanlığı. (2017). Türkiye 'nin Deaş ile mücadelesi. 11 16, 2018 tarihinde icisleri.gov.tr: https://www.icisleri.gov.tr/kurumlar/mia.gov.tr/Genel/deas\%CC\%A7\%207\%20temmu z.pdf adresinden alındi.

Konstantiniyye, (1436). 1: 3-45. https://archive.org/details/Konstantiniyye1_201605 Erişim Tarihi: 13.03.2019.

Manaz, A., (2020). Daesh terrorist organization, ASSAM Uluslararası Hakemli Dergi, 7(16), 58-79.

Okur, K. H., (2017). DEAŞ terör örgütü'nün ideolojisi ve dini söylemi, TDV Kagem Bülten, 5 (1): 1-68.

Öztop, F., (2021). Yabancı terörist savaşçıların motivasyon faktörleri: DEAŞ ve YPG çerçevesinde bir değerlendirme, Barış Araştırmaları ve Çatışma Çözümleri Dergisi, 9(1), 97-131.

Sandıklı, A., (2015). Terörün geldiği yeni boyut: IŞİD örneği, Bilge Adamlar Kurulu Raporu, Bilgesam Yayınları, 67: 7-46.

Smith, A., (2018). Seçilmiş halklar. İstanbul: Alfa Yayıncılık.

Şen, Y. F., (2015). Terörün toplumlar üzerindeki sosyo-ekonomik etkilerine bakış: Pkk terörü ve Ağrı gerçeği, A ̆grı İbrahim Çeçen Üniversitesi Sosyal Bilimler Dergisi, 1 (2): 17-70.

Şenol, D., Erdem, S., \& Erdem, E., (2016). IŞİD: Küresel bir terör örgütü, Fırat Üniversitesi Sosyal Bilimler Dergisi, 277-292.

Teltik, M., (2019). Irak-Şam İslam Devleti IŞID/DEAŞ: İdeolojisi, yapısı, propaganda araçları ve eylemleri, Yayımlanmamış Yüksek Lisans Tezi,Gaziantep Üniversitesi, Sosyal Bilimler Ensitütüsü. Gaziantep.

Yaşa, A., \& Yılmaz, M., (2020). Terör örgütleriyle mücadele sürecinde ekonomik istihbaratın rolü: DEAŞ örneği, Haliç Üniversitesi Sosyal Bilimleri Dergisi, 3(1), 107-130.

Yeşiltaş, M., \& Duran, B., (2018). Ortadoğu'da devlet dışı silahlı aktörler, İstanbul: Seta.

Yıldırım, S. G., (2018). IŞİD’in toplumsal ve küresel dinamikleri, Uşak Üniversitesi Sosyal Bilimler Dergisi, 170-182. 